\title{
The emerging role of dendritic cells in the host immune response against Helicobacter pylori
}

\author{
Steve Oghumu ${ }^{1,2}$ and Abhay Satoskar ${ }^{1 *}$ \\ ${ }^{1}$ Department of Pathology, Ohio State University Medical Center, Columbus, OH, USA \\ 2 Department of Oral Biology, Ohio State University College of Dentistry, Columbus, OH, USA \\ *Correspondence: abhay.satoskar@osumc.edu
}

Edited by:

Christine Anne Biron, Brown University, USA

Reviewed by:

Cheol-Heui Yun, Seoul National University, South Korea

Heinrich Korner, Menzies Research Institute Tasmania, Australia

Keywords: Helicobacter, cytotoxin, microRNA, adenocarcinoma, dendritic, cytokine

\section{A commentary on}

Inflammatory cytokine and microRNA responses of primary human dendritic cells cultures with Helicobacter pylori strains

by Hocès de la Guardia, A., Staedel, C., Kaafarany, I., Clément, A., Roubaud Baudron, C., Mégraud, F., et al. (2013). Front Microbiol. 4:236. doi: 10.3389/fmicb.2013.00236

Host cell interactions with bacterial pathogens trigger a wide variety of complex cellular signaling pathways that ultimately determine disease outcome. These inflammatory signaling cascades can often be traced back to specific virulence factors within the pathogen, which interact with unique host cells that come in contact with the invading organism. Ex vivo model systems which recapitulate the key events of human infection have helped to clarify these signaling activities with the critical molecules involved in the process. This was exemplified in the study conducted by Hocès de la Guardia et al. (2013) on Helicobacter pylori, which causes chronic active gastritis and peptic ulcer disease in humans. H. pylori infection has also been considered to be a risk factor for the development of gastric adenocarcinoma and mucosa-associated lymphoid tissue (MALT) lymphoma in some patients (Parsonnet et al., 1991, 1994). Type I strains contain the virulence factor cytotoxin-associated gene A (CagA), which has been shown to mediate the pathology associated with intestinal disease caused by $H$. pylori (Censini et al., 1996).

Studies evaluating pro-inflammatory immune responses against $H$. pylori infection have mainly been based on in vitro models using the AGS gastric epithelial cell line. However, it is becoming increasingly clear that interactions between pathogen and gut associated immune cells, particularly dendritic cells (DCs), play a major role in directing the nature of the adaptive immune response against $H$. pylori (Shiu and Blanchard, 2013). It is therefore critical to define mechanisms by which $H$. pylori modulates DC function. Interactions between $H$. pylori and DCs occur either in the gut lumen where mucosal DCs insert dendrites through the tight junctions of the gut epithelial monolayer (Rescigno et al., 2001), or within Peyer's patches in the small intestine where resident DCs phagocytose bacteria (Nagai et al., 2007). Mediated primarily by Tolllike receptors (TLRs) expressed on their cell membrane, DCs recognize pathogen associated molecular patterns (PAMPs) present on $H$. pylori, an interaction which triggers host cell signaling cascades that are vital for the initiation of the host immune response (Rad et al., 2009; Kabisch et al., 2014; Smith, 2014). Consistent with previous findings, the study by Hocès de la Guardia et al. (2013) observed enhanced production of TNF $\alpha$, IL- 6 and IL-10 by H. pylori infected DCs (Rad et al., 2009). In contrast with Escherichia coli-derived LPS (which signals primarily through TLR4), production of these cytokines was delayed in H. pylori infected DCs, suggesting differential mechanisms of activation, possibly through TLR8 and TLR9 signaling pathways. Moreover, production of IL-10 was significantly enhanced in DCs co-cultured with $H$. pylori, which fosters an anti-inflammatory microenvironment mediated by signaling through TLR2 and DC-SIGN (Rad et al., 2009; Fehlings et al., 2012). These important findings support the notion that pathogen-derived factors are important modulators of the host immune response which ultimately affects the outcome of disease.

An important finding by the authors of this study was the preferential induction of the cytokine IL- 23 by DCs cultured with cag Pathogenicity Island (cagPAI)containing $H$. pylori strains. While some papers report similar findings (Khamri et al., 2010; Tanaka et al., 2010), others indicate that cytokine production by H. pylori-infected DCs is cagPAI independent (Kao et al., 2010; Horvath et al., 2012). Additional studies will be required to clarify the effect of cagPAI in skewing the host immune response against H. pylori. It is possible that the type of DCs, bacterial strains and experimental conditions utilized affect the results obtained in these various studies. Nevertheless, the ability of $H$. pylori to induce IL-23 production in cultured DCs has been validated by this study. The production of IL-23 by $H$. pylori infected DCs has potential implications in the induction and maintenance of Th-17 responses, which could affect the development of gastritis during $H$. pylori infection. 
The studies conducted by Hocès de la Guardia et al. (2013) further showed a temporal regulation of miRNAs (miR146a and miR-155) by $H$. pylori which, although not dependent on the cagPAI, significantly affected the expression of pro-inflammatory cytokines (TNF $\alpha$ and IL-10). A role for these miRNAs (particularly miR-155) in fine tuning of TNF- and NFкB-mediated inflammatory responses was well established by loss-of-function assays using antisense miRNAs which inhibit the activity of miR-146a and miR155. These miRNAs have previously been linked to chronic inflammatory diseases (Sonkoly and Pivarcsi, 2009) and lymphoma development (Costinean et al., 2006). It is therefore of great interest to investigate how the deregulation of miR146, miR-155 and other miRNAs contributes to the pathologies and complications associated with $H$. pylori infection.

The article by Hocès de la Guardia et al. (2013) has significantly impacted the field by clearly defining $H$. pylori mediated inflammatory response modulation using an ex vivo model system of primary human DCs. Using this ex vivo co-culture system, the authors were able to establish a role for $H$. pylori cagPAI in directing the host adaptive immune response toward a Th17 profile by inducing IL-23 production in DCs. Therapeutic approaches that target key host response mediators modulated by $H$. pylori could subsequently be exploited in the management of $H$. pylori infection and its associated pathologies.

\section{REFERENCES}

Censini, S., Lange, C., Xiang, Z., Crabtree, J. E., Ghiara, P., Borodovsky, M., et al. (1996). cag, a pathogenicity island of Helicobacter pylori, encodes type I-specific and disease-associated virulence factors. Proc. Natl. Acad. Sci. U.S.A. 93, 14648-14653. doi: 10.1073/pnas.93.25.14648
Costinean, S., Zanesi, N., Pekarsky, Y., Tili, E., Volinia, S., Heerema, N., et al. (2006). Pre-B cell proliferation and lymphoblastic leukemia/high-grade lymphoma in $\mathrm{E}(\mathrm{mu})-\mathrm{miR} 155$ transgenic mice. Proc. Natl. Acad. Sci. U.S.A. 103, 7024-7029. doi: 10.1073/pnas.0602266103

Fehlings, M., Drobbe, L., Moos, V., Renner Viveros, P., Hagen, J., Beigier-Bompadre, M., et al. (2012). Comparative analysis of the interaction of Helicobacter pylori with human dendritic cells, macrophages, and monocytes. Infect. Immun. 80, 2724-2734. doi: 10.1128/IAI.00381-12

Hocès de la Guardia, A., Staedel, C., Kaafarany, I. Clément, A., Roubaud Baudron, C., Mégraud, F., et al. (2013). Inflammatory cytokine and microRNA responses of primary human dendritic cells cultures with Helicobacter pylori strains. Front. Microbiol. 4:236. doi: 10.3389/fmicb.2013.00236

Horvath, D. J. Jr., Washington, M. K., Cope, V. A., and Algood, H. M. (2012). IL-23 Contributes to control of chronic Helicobacter pylori infection and the development of $\mathrm{T}$ Helper responses in a mouse model. Front. Immunol. 3:56. doi: 10.3389/fimmu.2012.00056

Kabisch, R., Mejias-Luque, R., Gerhard, M., and Prinz, C. (2014). Involvement of toll-like receptors on Helicobacter pylori-induced immunity. PLOS ONE 9:e104804. doi: 10.1371/journal.pone.0104804

Kao, J. Y., Zhang, M., Miller, M. J., Mills, J. C., Wang, B., Liu, M., et al. (2010). Helicobacter pylori immune escape is mediated by dendritic cell-induced Treg skewing and Th17 suppression in mice. Gastroenterology 138, 1046-1054. doi: 10.1053/j.gastro.2009.11.043

Khamri, W., Walker, M. M., Clark, P., Atherton, J. C., Thursz, M. R., Bamford, K. B., et al. (2010). Helicobacter pylori stimulates dendritic cells to induce interleukin-17 expression from CD4+ T lymphocytes. Infect. Immun. 78, 845-853. doi: 10.1128/IAI.00524-09

Nagai, S., Mimuro, H., Yamada, T., Baba, Y., Moro, K., Nochi, T., et al. (2007). Role of Peyer's patches in the induction of Helicobacter pylori-induced gastritis. Proc. Natl. Acad. Sci. U.S.A. 104, 8971-8976. doi: 10.1073/pnas.0609014104

Parsonnet, J., Friedman, G. D., Vandersteen, D. P., Chang, Y., Vogelman, J. H., Orentreich, N., et al. (1991). Helicobacter pylori infection and the risk of gastric carcinoma. N. Engl. J. Med. 325, 1127-1131. doi: 10.1056/NEJM1991101 73251603

Parsonnet, J., Hansen, S., Rodriguez, L., Gelb, A. B., Warnke, R. A., Jellum, E., et al. (1994).
Helicobacter pylori infection and gastric lymphoma. N. Engl. J. Med. 330, 1267-1271. doi: 10.1056/NEJM199405053301803

Rad, R., Ballhorn, W., Voland, P., Eisenacher, K., Mages, J., Rad, L., et al. (2009). Extracellular and intracellular pattern recognition receptors cooperate in the recognition of Helicobacter pylori. Gastroenterology 136, 2247-2257. doi 10.1053/j.gastro.2009.02.066

Rescigno, M., Urbano, M., Valzasina, B., Francolini, M., Rotta, G., Bonasio, R., et al. (2001). Dendritic cells express tight junction proteins and penetrate gut epithelial monolayers to sample bacteria. Nat. Immunol. 2, 361-367. doi: 10.1038/86373

Shiu, J., and Blanchard, T. G. (2013). Dendritic cell function in the host response to Helicobacter pylori infection of the gastric mucosa. Pathog. Dis. 67, 46-53. doi: 10.1111/2049-632x.12014

Smith, S. M. (2014). Role of Toll-like receptors in Helicobacter pylori infection and immunity. World J. Gastrointest. Pathophysiol. 5, 133-146. doi: 10.4291/wjgp.v5.i3.133

Sonkoly, E., and Pivarcsi, A. (2009). microRNAs in inflammation. Int. Rev. Immunol. 28, 535-561. doi: 10.3109/08830180903208303

Tanaka, H., Yoshida, M., Nishiumi, S., Ohnishi, N., Kobayashi, K., Yamamoto, K., et al. (2010). The CagA protein of Helicobacter pylori suppresses the functions of dendritic cell in mice. Arch. Biochem. Biophys. 498, 35-42. doi: 10.1016/j.abb.2010.03.021

Conflict of Interest Statement: The authors declare that the research was conducted in the absence of any commercial or financial relationships that could be construed as a potential conflict of interest.

Received: 04 July 2014; accepted: 06 October 2014; published online: 24 October 2014.

Citation: Oghumu S and Satoskar A (2014) The emerging role of dendritic cells in the host immune response against Helicobacter pylori. Front. Microbiol. 5:560. doi: $10.3389 /$ fmicb.2014.00560

This article was submitted to the journal Frontiers in Microbiology.

Copyright (c) 2014 Oghumu and Satoskar. This is an open-access article distributed under the terms of the Creative Commons Attribution License (CC BY). The use, distribution or reproduction in other forums is permitted, provided the original author(s) or licensor are credited and that the original publication in this journal is cited, in accordance with accepted academic practice. No use, distribution or reproduction is permitted which does not comply with these terms. 